\title{
Access to Health Care for Undocumented Migrants: A Comparative Policy Analysis of England and the Netherlands
}

\author{
Kor Grit \\ Institute of Health Policy and Management, Erasmus University \\ Rotterdam \\ Joost J. den Otter \\ International Rehabilitation Council for Torture Victims \\ Anneke Spreij \\ Dutch Transplantation Foundation
}

\begin{abstract}
The presence of undocumented migrants is increasing in many Western countries despite wide-ranging attempts by governments to increase border security. Measures taken to control the influx of immigrants include policies that restrict access to publicly funded health care for undocumented migrants. These restrictions to health care access are controversial, and evidence suggests they do not always have the intended effect. This study provides a comparative analysis of institutional, actor-related, and contextual factors that have influenced health care policy development on undocumented migrants in England and the Netherlands. For undocumented migrants, England restricts its access to care at the point of service, while the Netherlands restricts through the payment system for services. The study includes an analysis of policy papers and semistructured, in-depth interviews with various actors in both countries. Findings confirm the influence of such contextual factors as immigration considerations and cost concerns on health care policy making in this area. However, these factors cannot explain the differences between the two countries. Previously enacted policies, especially the organization of the health care system, affected the kind of restrictions for undocumented migrants. Concerns about the side effects of generous treatment of undocumented migrants on other groups played a substantial role in formulating restrictive policies in both countries. Evidently, policy development and implementation is critically affected by institutional rules, which govern the degree of influence that doctors and professional medical associations have on the policy process.
\end{abstract}

The authors gratefully thank all the respondents who agreed to take part in our research and who gave us valuable information and insights during the interviews. Previous versions of this article have benefited from discussions in the research seminar held by the Health Care Governance section of the Institute of Health, Policy, and Management of the Erasmus University Rotterdam and from the critical comments by the editor and anonymous reviewers of JHPPL.

Journal of Health Politics, Policy and Law, Vol. 37, No. 1, February 2012

DOI 10.1215/03616878-1496011 @ C 2012 by Duke University Press 


\section{Introduction}

Immigration is high on the policy agenda of many countries in the Organisation for Economic Co-operation and Development (OECD). National governments have made considerable efforts to tighten their borders. Nevertheless, in the last decade international migration has continued to rise, with about 3.6 million immigrants entering OECD countries in 2007 (OECD 2009a). Although the OECD predicts the first decline in migrant numbers in many years because of the economic crisis, governments are still anxious about immigration, partly because of the perception that immigrants compete for scarce jobs in OECD (2009b) labor markets. There are significant flows of illegal migration as well, but given its secretive nature accurate data are unavailable. Measures taken in the last decade to try to control illegal or undocumented migrant flows include stricter border control, identity checks, forced return migration, and the curtailment or denial of social security rights for undocumented migrants (immigrants without a residence permit). ${ }^{1}$ Many Western countries have adopted policies that exclude undocumented migrants from publicly funded health care, with the exception of life-threatening situations or, in some countries, if the situation poses a risk to public health (Calavita 1996; Okie 2007; Chauvin, Parizot, and Simonnot 2009; Romero-Ortuno 2004).

Denying undocumented migrants access to nonemergency health care often stems from the idea that they are free riders, taking advantage of public services without contributing to public funding (Dwyer 2004). Another concern is the belief that providing free health care services may work as a pull factor. In view of rising health care expenditures in Western countries, it may seem reasonable to limit access to care for undocumented migrants to contain costs. Restrictive measures for the use of public services by undocumented migrants are quite normal, since every country has framed national policies that primarily focus on legal residents. Every social security system makes a distinction between residents and nonresidents. Proponents of limitations for undocumented migrants argue that restrictive measures are justifiable, if they deny only nonemergency care to people who stay in the country illegally. They acknowledge that aid

1. Undocumented migrants are people who enter a country without correct legal documents and/or reside in a country without a valid residence permit, such as a visa or asylum document. They are liable to be deported for issues related to their immigration status. Because these people are in a country unlawfully, they are often referred to as "illegal migrants." This term is criticized because of its connotation with criminality, since most undocumented migrants are not criminals. Nongovernmental organizations (NGOs), local authorities, professionals from diverse fields, and the Council of Europe (2006) prefer the term "undocumented migrant" or "irregular migrant" as opposed to "illegal migrant" (PICUM 2007). 
in the case of emergency is a basic human right and that emergency care should be provided because of ethical reasons. Even proponents of restrictions of health care recognize that health care in life-threatening situations is an exception to the general rule that limits the scope of social security systems to legal residents.

Opponents argue that societies should offer comprehensive health care to all who stay within their borders, including undocumented migrants. They object to restrictions for factual, normative, and legal reasons. Empirical arguments against restricting care refer to doubts about potential cost savings. The grounds for financial arguments are weak, as denying nonemergency treatment could lead to expensive emergency treatment at a more advanced stage of disease. Spain's health care policy for undocumented migrants already reflects this. In 2000 the Spanish government passed a law that constituted the right of undocumented migrants to be fully entitled to health care under the same conditions as Spaniards, because an official study showed that the cost involved would be negligible (Romero-Ortuno 2004). Similarly, there is no evidence that providing health services is a strong motive for migration. Although many different causes induce people to migrate — such as family reunion, economic considerations, political persecution, violent conflict, and natural disasters health care concerns are not among the most important motives (United Nations Educational, Scientific and Cultural Organisation 2005). Moreover, the journey to more affluent countries is often long, risky, and very expensive (especially when it involves human trafficking), conditions that are unsuitable for ill people (Landelijke Commissie Medische Aspecten van het Vreemdelingenbeleid [LCMAV] 2004).

Ethical arguments for providing care for migrants are mostly based on the concern that undocumented migrants are among the most destitute in society; they live in fear of being discovered and face difficulties in the host country such as poverty, language problems, and homelessness (Ashcroft 2005; Pollard and Savulescu 2004; Singer 2004; Jaklevic 2001). It is often considered immoral to restrict access to health care for this already vulnerable group of people. Dwyer (2004) has framed the normative issue in terms of social justice and social responsibility. Societies should take responsibility for undocumented migrants if they do unsavory jobs under bad conditions for the lowest wages. In many respects, undocumented migrants contribute to society as diligent workers, good neighbors, or active participants in the community, even though they are not citizens or legal residents. This implies that the social responsibility to care for undocumented workers is higher than for medical visitors. 
Human rights arguments are frequently put forward, too (Hall 2006; Cole 2007). The most commonly mentioned human rights treaty is the International Covenant on Economic, Social and Cultural Rights (ICESCR), ratified by almost all countries. It stipulates that health care services should be accessible to everyone within the jurisdiction of a state, without discrimination. Although undocumented migrants are not lawfully residing in a country, they are within the jurisdiction of that country and as such are beneficiaries of this right. The state's obligations concerning access to health care are well summarized in social treaties such as the ICESCR (especially article 12 and General Comment 14), the European Code of Social Security, and the European Convention on Human Rights and Biomedicine (especially in article 3 ). The social right to health is detailed in these treaties. It creates obligations on the part of the state to place the subject matter of treaties dealing with the right to health on the political and legislative agenda. Article 12 (para. 34) of the ICESCR, for instance, declares: "States are under the obligation to respect the right to health by, inter alia, refraining from denying or limiting equal access for all persons, including prisoners and detainees, minorities, asylum seekers and illegal migrants, to preventive, curative and palliative health services." Health care is thus a special case of social security, which necessitates government interventions to guarantee and protect the rights of individuals. Governments have no choice in whether or not to intervene; they can only choose the manner in which they do so. Although there are minor differences between the treaties mentioned, the main message is that health care should be available, accessible (physical, nondiscriminatory, and economic), of good quality, and culturally acceptable (De Groot 2005).

Clearly, policies limiting health care access for undocumented migrants are controversial. Evidence suggests that they are unlikely to have the intended effect of discouraging illegal immigration or making migrants return home (LCMAV 2004; Burnett and Peel 2001; Fallek 1997). The first question is why several Western countries adopted these policies despite the counterarguments. In practice, differences in access exist not only between countries but also within them (Platform for International Cooperation on Undocumented Migrants [PICUM] 2007). Countries restrict access either through payment for services or at the point of service (limited list of services). This raises additional questions: Why does this matter? What are the effects of the two different restricting policies in practice? Demanding payment for all services rendered to undocumented migrants sounds stingy and inhumane, whereas a nonrestrictive policy of 
free care sounds more generous and humane. Paradoxically, however, as we show in this article, systems with financial restrictions on all services can be more accessible to undocumented migrants than systems that offer free care with the exclusion of some services.

This article investigates these questions and the policy paradox in a comparative analysis of English and Dutch health care policy development and implementation practices related to undocumented migrants. Both countries have recently changed their regulations in this area and have witnessed a marked increase in immigration in the past decade, although immigration to the Netherlands in the last few years has declined. Accurate data are unavailable, but in 2007 the estimate was between 417,000 and 863,000 undocumented migrants (1.0 percent of total population) in the United Kingdom (Gordon et al. 2009) and in 2005 between 75,000 and 185,000 ( 0.8 percent of total population) in the Netherlands (Van der Heijden et al. 2006). In both countries undocumented migrants have clustered in or near the big cities where there is always a need for (cheap) labor. General practitioners and accident and emergency (A\&E) departments in these areas deliver most of the health care (PICUM 2007; Veenema, Wiegers, and Deville 2009). The estimated rates for the United Kingdom and the Netherlands are below the average (1.8 percent) of Western countries, and far below the United States (OECD 2009b). Despite a similar political context characterized by combating migration and making life for unlawful residents progressively more difficult, the policies both England and the Netherlands developed to deal with undocumented migrants in the health care system are not the same.

A comparison of these two countries provides the opportunity to consider whether having a privatized health insurance system or a tax-funded National Health Service (NHS) leads to differing health care policies for undocumented migrants. In England, health care is mostly provided by the NHS and financed through national taxes. An important feature is that care is free at the point of delivery for everyone ordinarily resident in the United Kingdom. ${ }^{2}$ The NHS is run by the Department of Health and can be classified as a government-owned and -operated system in which the government provides a salary or directly pays for services rendered (Hacker 2004; Glaser 1991). The Netherlands has a private health insur-

2. "Ordinarily resident" is a common concept in law, a concept interpreted by the House of Lords in 1982 to refer to individuals living lawfully in the United Kingdom voluntarily and for settled purposes as part of the regular order of their lives for the time being, with an identifiable purpose for their residence there that has a sufficient degree of continuity to be properly described as settled (Department of Health 2004a). 
ance system, which operates under regulation and supervision of central government. The 2006 Health Insurance Act introduced managed competition, and all Dutch citizens are required by this law to have a basic health insurance policy. Offered by competing insurance companies, such a policy always includes a standard package of essential health care (Abbing 2006; Schäfer et al. 2010). The major players in the Dutch health care system - the insurance companies and health care providers - are private organizations. Thus the health care system is a public-private mixture in which the Ministry of Health, Welfare and Sports (Ministry of HWS) determines the overall strategic development and regulatory framework, the insurance companies set the premium and administer payments for the rendered care, and the medical profession provides the services.

In this article we focus on health care policy development and implementation for undocumented migrants in the light of several factors determining policy making, including (1) contextual factors (cost-containment and migration issues), (2) key actors, and (3) institutional factors (mode of governance and health care system). Together these factors form the explanatory framework of analysis.

First, policy making is determined by the context in which policy is formulated and executed (Buse, Mays, and Walt 2005). The need to constrain costs and deal with migration issues are two important pressures in this context. We explore the role of cost consideration and the ongoing tensions and conflicting ideas that both the English and Dutch public have about migration and multiculturalism.

Second, we compare the degree of influence and power that English and Dutch actors have in creating and implementing health care policies. In this case, as we explain later, medical doctors could be crucial actors in policy making and implementation. Physicians have a substantial degree of professional autonomy, and whether they treat undocumented migrants is often left to their discretion. Weatherley (1980) stated that while doctors are responsive to public policy, they might also be subject to other influences, which policy makers cannot easily control. We also focus on other actors at the micro level that could have some discretionary power (Lipsky 1980) in the access of undocumented migrants to health care. Street-level organizations, which deliver public services, do more than simply "apply the law." "They also engage in informal and discretionary practices that effectively 'make the law,' essentially constituting an 'extralegal' mode of determining "who gets what and how" (Brodkin and Majmundar 2010: 828). If policy implementation requires discretionary decision making at 
the point of delivery, the choices of providers should be understood as the continuation of policy politics by other means (Brodkin 2008).

Third, institutional factors affect the formation of policies. Institutional factors refer to the existing structures, which distribute formal power among actors. Although policy actors undoubtedly have their own interests, the way they pursue their goals and the results of the actors' activities are strongly influenced by institutional factors (Scharpf 2000). Such factors determine the amount of influence that actors have on the policy process and the level of access they have to government debate (Hemerijck 2001; Steinmo and Watts 1995). Significant differences exist between England and the Netherlands in this respect. England is characterized by a pluralist mode of governance, where the state cannot be "captured" by any one group of stakeholders. In contrast, the Netherlands is characterized by a corporatist mode of governance with various stakeholders deeply engaged in the health care policy process and implementation, although combined with a high degree of government involvement to safeguard universal access to good quality health care. The Dutch medical association will accept only the expenditure control and rules that it freely negotiates, whereas the British have far fewer options for successful bilateral negotiations (Glaser 1994). Whereas the English have a hierarchical medical system and a veto-free political system, the Dutch combine a decentralized medical system with a veto-ridden political framework (Hacker 2004).

Another institutional factor refers to policy feedback effects or the impact of existing policies on politics and policy development (Lowi 1972; Heclo 1974; Pierson 1993; Béland 2010). Governments do not start from a tabula rasa but are influenced by policy inheritances (Heclo 1974). The concept of policy feedback refers to the impact of previously enacted policies on future political behavior and policy choices (Béland 2010). The range of feasible health care arrangements for undocumented migrants is affected by how the national health care system is funded. Comparing England and the Netherlands highlights the different payment policies for providers taking care of undocumented migrants that can impede or facilitate health care access.

\section{Methods}

This study uses cross-national comparison to identify similarities and differences between two countries. The cases of England and the Netherlands are examples of how different political systems and different health care 
systems approach the same problem. Both countries faced rising numbers of undocumented migrants when these policies were being developed. The knowledge gained helps us understand and interpret diverse policy processes and outcomes between countries (Ragin 1987).

We used case-oriented comparative analysis; it involves qualitative research that views cases as configurations, that is, as combinations of characteristics (ibid.). This holistic approach permitted us to analyze the institutional structures, the role of the actors, and the influence of the different reimbursement systems in combination with each other and in relation to the wider context.

For pragmatic reasons, the scope of research was limited to general practice (GP), hospital, and mental care for migrants without legal residence papers. The findings of this study rely on an analysis of policy papers and law texts, and on interviews undertaken with a broad range of key figures in this field. The policy papers and law texts were used to create an overview of current regulations on access to care for undocumented migrants and the reimbursement systems for health care providers. The sources of the policy papers used for this purpose were the English Department of Health and the Dutch Ministry of HWS. This enabled us to identify the official government perspective on this issue.

Semistructured, in-depth interviews with open-ended questions were carried out with key actors, such as health care professionals, policy makers at the local and national level, NGOs, and professional medical associations. These data give a sense of how these actors perceive the influential factors behind a specific policy. This approach makes it possible to reconstruct the actors' intentions, which can depart from official policy argumentation. The focus on intentions and "perceptions of influential factors" could be a weakness in our approach, because it is difficult to produce counterfactual evidence. However, the framing of problems and reasons by policy actors is highly relevant in the policy-making process (Stone 2002). The interviewees were chosen either because of their organization's involvement in lobbying or consulting for government health policy makers, or because as professionals they worked with these policies in their jobs. No undocumented migrants were interviewed. Their input in the policy process is negligible because of the inherent problem of having to stay "invisible" as unlawful residents. Although undocumented migrants were not included in the policy process, medical associations and NGOs gave voice to the interests of these otherwise "silent" groups. In total, seventeen people were interviewed, nine in the Netherlands and eight in England (table 1). The interviews took place in 2007 and 2008. 
Table 1 Interviewees in England and the Netherlands, 2007 and 2008

\begin{tabular}{|c|c|c|c|}
\hline Country & $\begin{array}{l}\text { Stakeholder } \\
\text { Category }\end{array}$ & $\begin{array}{l}\text { Respondent's } \\
\text { Job Title }\end{array}$ & $\begin{array}{l}\text { Respondent's } \\
\text { Organization }\end{array}$ \\
\hline \multirow[t]{8}{*}{ England } & \multirow[t]{3}{*}{ NGO } & $\begin{array}{l}\text { Coordinator, refugee } \\
\text { health network }\end{array}$ & Medact \\
\hline & & Project manager & $\begin{array}{l}\text { Project London Walk-in } \\
\text { Health Clinic of } \\
\text { Medicines du Monde }\end{array}$ \\
\hline & & $\begin{array}{l}\text { Head of policy and } \\
\text { deputy CEO }\end{array}$ & $\begin{array}{l}\text { African HIV Policy } \\
\text { Network }\end{array}$ \\
\hline & \multirow[t]{4}{*}{ Provider } & General practitioner & $\begin{array}{l}\text { GP practice in an } \\
\text { ethnically highly } \\
\text { diverse area of London }\end{array}$ \\
\hline & & Senior policy adviser & $\begin{array}{l}\text { Professional medical } \\
\text { association (British } \\
\text { Medical Association) }\end{array}$ \\
\hline & & Psychologist & $\begin{array}{l}\text { Primary care trust in } \\
\text { London }\end{array}$ \\
\hline & & HIV specialist & Hospital in London \\
\hline & Government & Policy head & $\begin{array}{l}\text { Department of Health, } \\
\text { Overseas Visitors } \\
\text { Policy Unit }\end{array}$ \\
\hline \multirow[t]{10}{*}{ The Netherlands } & \multirow[t]{3}{*}{ NGO } & Policy adviser & Rotterdam \\
\hline & & & $\begin{array}{l}\text { Undocumented Migrants } \\
\text { Office }\end{array}$ \\
\hline & & $\begin{array}{l}\text { Policy officer, social } \\
\text { and legal affairs }\end{array}$ & STI AIDS Netherlands \\
\hline & \multirow[t]{4}{*}{ Provider } & $\begin{array}{l}\text { Policy adviser, asylum } \\
\text { seekers, and undocu- } \\
\text { mented migrants }\end{array}$ & $\begin{array}{l}\text { Branch organization of } \\
\text { mental health } \\
\text { institutions (Mental } \\
\text { Healthcare Netherlands) }\end{array}$ \\
\hline & & $\begin{array}{l}\text { Chairman of the board } \\
\text { of directors }\end{array}$ & Inner-city hospital \\
\hline & & Surgeon & Inner-city hospital \\
\hline & & Policy adviser & $\begin{array}{l}\text { Professional medical } \\
\text { association (Royal } \\
\text { Dutch Medical } \\
\text { Association) }\end{array}$ \\
\hline & \multirow[t]{3}{*}{ Government } & $\begin{array}{l}\text { Health policy } \\
\text { coordinator }\end{array}$ & $\begin{array}{l}\text { Municipality of } \\
\text { Rotterdam }\end{array}$ \\
\hline & & $\begin{array}{l}\text { Head of division, } \\
\text { health insurance } \\
\text { and treaties }\end{array}$ & $\begin{array}{l}\text { Ministry of Health, } \\
\text { Welfare and Sports }\end{array}$ \\
\hline & & Senior policy adviser & $\begin{array}{l}\text { Ministry of Health, } \\
\text { Welfare and Sports }\end{array}$ \\
\hline
\end{tabular}

Source: Authors 
The interview questions related to actual levels of health care access for undocumented migrants and the role of the representative's organization in developing, carrying out, or influencing health care policies. Each interviewee was also asked whom he or she considered the important actors in the policy-making process to provide health care for undocumented migrants. This helped us identify and speak to the relevant people in both countries. One actor in the policy process that we were unable to interview, even though its involvement was indicated, is the Home Office in England. Its involvement became apparent through the other interviews, but unfortunately it proved impossible to arrange an interview on short notice. ${ }^{3}$

Respondents were asked what they considered important determinants influencing the development of policies, and about the health care services that undocumented migrants receive in practice. We asked the respondents for the reasons they considered relevant (e.g., human rights and ethical reasons). We also asked about the roles of various actors and contextual factors such as economic considerations and society's attitude toward immigrants and national immigration policies. Extra attention was paid to access to HIV treatment for undocumented migrants because the regulations governing this are very different in England and the Netherlands. This is why in both countries we interviewed someone from an NGO dealing specifically with HIV.

On average, the interviews lasted an hour, varying from thirty minutes to two hours. Two transcripts were constructed from written notes made during the individual interviews, but the majority of the interviews were recorded and transcribed verbatim. A codebook was used to analyze the interviews. The data were coded by theme. Themes were informed by the explanatory framework or developed during the interviews: health care access, HIV treatment, ethical considerations, human rights arguments, the role of actors, contextual factors such as economics and immigration, the policy development process, and the impact of the health care system.

3. The researcher gathering data abroad in England could not return on short notice, having accepted a new job. 


\section{Current Health Policies for Undocumented Migrants}

Undocumented migrants in England who require health care are subject to the provisions of the 1989 NHS Charges to Overseas Visitors Regulations, Statutory Instrument No. 306. These regulations put NHS hospitals under the obligation to ascertain the residential status of all patients. If patients are undocumented migrants, they must confirm their ability to pay in order to access nonemergency care. Medical treatment that is immediately necessary in the professional opinion of a medical practitioner must be provided irrespective of ability to pay, but charges still apply and the patient will be issued a bill. If patients cannot pay, hospitals must cover the costs from their own budgets. A number of NHS services are free to all patients regardless of resident status, such as accident and emergency services and the treatment of certain communicable diseases. For these health care services, hospitals are reimbursed through NHS funding. Notably, HIV is not included in the list of communicable diseases and is therefore excluded from the free care provisions; undocumented migrants in England are admitted to HIV treatment only when they can afford it (Taylor 2009). If undocumented migrants with HIV are critically ill, they may be admitted as long as there is immediate danger, but they will be charged after treatment.

Access to primary care is currently regulated by Health Service Circular 1999/018 (NHS Executive 1999). It stipulates that undocumented migrants in England are ineligible for free routine NHS primary care, meaning that GP practices can turn people away if they are unable to prove legal residence (unless it concerns immediately necessary care). However, GPs have the discretion to register anyone who applies at their practice. If undocumented migrants are accepted onto a practice's list of patients, they are entitled to free NHS primary care. The debate on who should provide proof is still going on. Some practices decided to accept an undocumented migrant only as a private patient and charge for services, whereas others comply with the General Medical Council (2006) code of professional ethics.

Mental health care services are free of charge when people are detained under the provisions of the Mental Health Act or when they are given as part of a court probation order. For other forms of mental health treatment, including emergency care, undocumented migrants are charged after treatment.

In the Netherlands, people with no legal status are excluded from buy- 
ing health insurance because of the Linkage law (Koppelingswet). This law is embedded in the current Aliens Act (2000) and links "entitlement to benefits in kind, facilities and social security benefits" to the condition of lawful residence. Thus undocumented migrants have no legal right to health care services unless they can pay for them. On the basis of article 10.2 in the Aliens Act there are two exceptions to this rule: medically necessary care and care needed to protect public health. Treatment for HIV infection is considered medically necessary and is thus readily accessible, from preventive counseling to academic hospital care. Officially, care is never free of charge, since providers are obligated to bill patients. Only when it is impossible to collect the debt from patients can providers apply for specific reimbursement schemes.

At the time of our study, different reimbursement schemes for primary and secondary health care providers offered health care services to undocumented migrants. These systems operated parallel to the normal payment systems. Unlike in England, Dutch hospitals could provide medically necessary care to undocumented migrants who were unable to pay and have the bill covered by a special provision for "dubious debtors" in their budget. Although insurers are expected to compensate hospitals for unpaid costs, the size of this provision was agreed on in annual negotiations between the hospital and health care insurers. Primary health care providers could apply for money from the Linkage fund (Koppelingsfonds) run by the Ministry of HWS (2006a) when they treated undocumented migrants who were unable to pay for services. Compulsory mental health treatment for undocumented migrants was paid for by the Ministry of HWS; there was no arrangement for noncompulsory treatment. ${ }^{4}$

In sum, undocumented migrants have formal access to health care except for some aspects of secondary care (for an overview, see table 2). English policy is more restrictive for care services deemed medically necessary but not immediately life threatening in the case of nontreatment, such as HIV treatment. In both countries, providers must charge undocumented migrants; however, some services are offered for free in England. Another notable difference is that the financial consequences are

4. A new Dutch law went into effect on January 1, 2009, to standardize arrangements in one fund for all types of care, including all mental health care services (www.st-ab.nl/1-08526 $. h t m)$. The financial reimbursement for providers varies between 80 and 100 percent. An important difference with previous regulations is that providers need a contract with the Dutch Health Care Insurance Board to be eligible for reimbursement. For example, currently only 26 of 102 Dutch hospitals are contracted to provide care for irregular migrants. The other hospitals may apply for financial reimbursement only in cases of emergency care. 


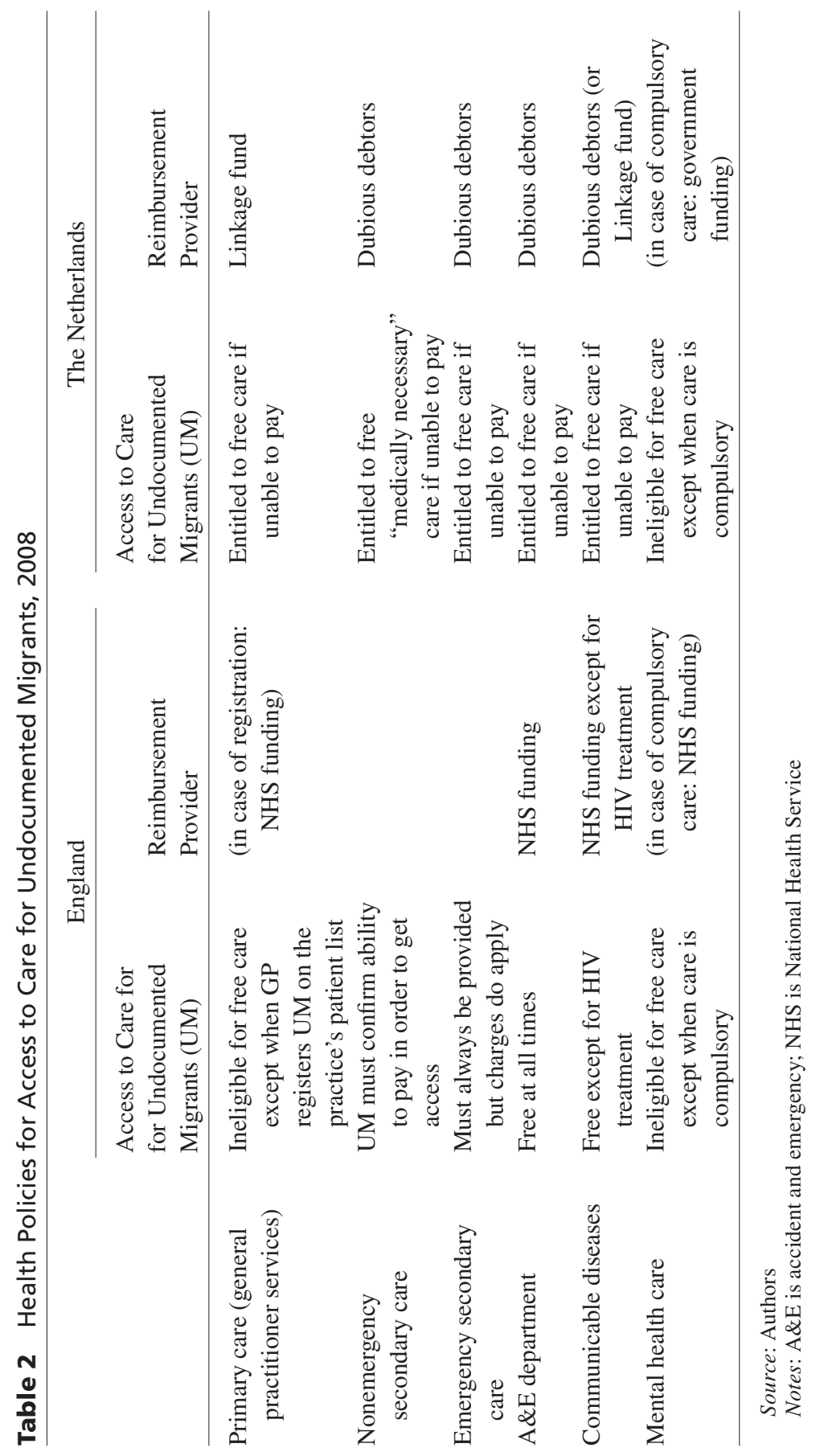


greater for English hospitals than for Dutch hospitals when undocumented migrants cannot pay for treatment.

\section{Possible Causes of Restrictions}

This section tries to explain why both countries have developed some restrictive measures for undocumented migrants despite empirical, normative, and juridical counterarguments. Possible causes are clustered around the following factors: (1) contextual factors (immigration and economic), (2) crucial stakeholders (doctors in this case study), and (3) the health care system.

\section{Contextual Factors}

In both England and the Netherlands, the societal and political attitude is increasingly characterized by opposition to immigration. Public attention is focused on problems about integration and perceived abuses of the social welfare system. Additionally, anti-Islamic sentiments are part of the wider context for the debate on migrants. This anti-immigrant context has influenced the actions of some politicians and policy makers, who want to be seen as concerned about immigration.

In both countries immigration policy is an important contextual factor influencing health care policies for migrants, since both countries aim to restrict the use of collective or public services by undocumented migrants. In the Netherlands, the Linkage law, which links entitlement to public benefits to the condition of lawful residence, is clearly intended to make life difficult for people without legal status. The Dutch government is particularly concerned that providing health care services to undocumented migrants may work as a pull factor. Representatives from the Ministry of HWS stated that nonurgent care for undocumented migrants should not be provided immediately because the Ministry of HWS believes this may work as an incentive for "health tourists" (used as a pejorative term for people traveling from abroad to receive free care and then returning home). It was pointed out that undocumented migrants would be given an ambiguous message if they were told to leave the country while they were receiving publicly funded health care. The representative from the English Department of Health stated that the government's main aims with the health care policies for undocumented migrants are "protecting the NHS for the people for whom it is intended" and "not contributing to any kind of incentive to people to stay here if they shouldn't be here" 
(policy head, Department of Health, Overseas Visitors Policy Unit, interview, December 7, 2007). In contrast to the Netherlands, access to health care is not considered a pull factor, although it is regarded as an incentive for immigrants to stay once they are in the country. In government documentation from 2003 (Department of Health 2003), health tourism is still put forward as an argument for proposing changes to the regulations. However, this has gradually changed, as the Department of Health and the Home Office have recognized that there are relatively few health tourists, and the primary concern is now with people living in England unlawfully. According to the former home secretary John Reid, "The public want people to play by the rules, and they don't like people who don't. Media stories about illegal immigrants getting access to housing, legal aid or NHS care may be exaggerated, but they do reflect an underlying concern that in the past we have not been tough enough in enforcing the rules" (Home Office 2007: 2).

The influence of immigration issues in England is also illustrated by the fact that health policies for migrants are a result of negotiations between the Department of Health and the Home Office, the government department responsible for immigration. The respondent from the Department of Health acknowledged that the Home Office looked at this matter from another perspective and indicated that it had to "find a route that will suit and serve both of us." Many other English interviewees pointed out the significant role of the Home Office in this matter, which most of them considered inappropriate.

Macroeconomic considerations of the health care costs of undocumented immigrants are not that important in either country and cannot explain the differences in restricting policies between both countries. Respondents from the Dutch Ministry of HWS acknowledged that it might be cheaper for government if undocumented migrants could insure themselves instead of relying on a special fund, but they pointed out that immigration considerations were more important than economic ones in the political debate. However, some other Dutch interviewees suspected that the reason for a partial reimbursement in the new law was to cut costs.

In England protecting NHS resources is among the goals of health care policies for migrants, but this aim is outweighed by issues related to capacity and to discouraging undocumented migrants from staying (Home Office 2007). For instance, with regard to HIV treatment, the House of Commons Health Committee (2005) has reported evidence that it is more cost-efficient to give undocumented migrants free access to antiretroviral 
drugs, but this economic argument has not had any impact on existing regulations.

\section{The Role of Doctors at the Policy Level}

At the policy level in both countries, professional medical associations are also powerful stakeholders. Because of institutional differences, the Dutch associations have more influence than their English counterparts. The strong influence of Dutch medical associations is illustrated by a new financial reimbursement arrangement to provide care to undocumented migrants covering "de jure" nearly the same care as for Dutch citizens (for more details, see section "Similarities and Differences in Policy and Practice," subsection "Interpretation of Human Rights"). The broad interpretation of "medically necessary care" can be attributed to the efforts of the associations.

The role of the English medical associations is comparatively limited, although they are in touch with the Department of Health on this issue. Partly this is due to divisions within the associations. According to one member of an association: "Some of them [their members] are very sympathetic to nondocumented, you know, to failed asylum seekers. Some of them much less so. So that is something that we have to negotiate on as an association" (senior policy adviser, professional medical association, interview, December 5, 2007).

There is also a difference in the degree of influence to which one believes the medical association is entitled. Whereas Dutch respondents see entitlement issues as matters for doctors to decide, a respondent of an English professional medical association is more inclined to describe this as a political decision: "It is for the government to decide entitlement, that is a political decision that needs to be made as a result of due democratic process . . . that is our basic policy, it is not for us to decide who is or who is not entitled" (senior policy adviser, professional medical association, interview, December 5, 2007). English NGOs particularly express regret at this situation: "We feel that doctors could make a big difference, but they don't. And then the British HIV Association, again, wealthy and powerful, but they don't have a political and policy remit. So I think we don't have all the players that could be influential here" (head of policy and deputy CEO, African HIV Policy Network, interview, December 10, 2007).

The interviewees explained these opinions by the difficulties that NHS doctors face in their jobs, such as long waiting lists and limited resources. 
One respondent said that NHS doctors simply have enough to worry about already. Someone else explained that busy services and long waiting lists could lead to a stricter interpretation by doctors of the entitlements of undocumented immigrants: "If they had more resources their definition of immediately necessary care would be looser. It's definitely to do with the pressure on the system, as well as to do with the legislation" (psychologist, primary care trust, interview, January 28, 2008). The lack of a reimbursement system for undocumented patients who cannot pay is another contributory factor.

Dutch medical associations are more active in the policy process. They believe that they have every right to influence democratic processes in all domains of health policy. As a consequence of the corporatist policy culture, the Ministry of HWS spends considerably more time communicating with stakeholders than the English Department of Health. The Ministry of HWS respondent stated: "The medical world has a good lobby in the ministry" (head of division, health insurance and treaties, Ministry of HWS, interview, November 22, 2007). This has resulted in payment systems for undocumented migrants such as the Linkage fund and the special "dubious debtors" budget. Dutch doctors are practically undivided on the issue of health care access for migrants. Another possible explanation is that most Dutch doctors are self-employed or in private partnerships that stand to lose money if they deliver unreimbursed care. Because of these various contextual factors, they lobby government intensively, carry out research, and use the media to promote the view that undocumented migrants should have access to care. Their successful lobbying has contributed to a payment system that could temper the possible resistance of members of doctors' associations to the policy of their association. In England, insufficient capacity at the local level combined with the absence of a payment system for treating undocumented migrants could have a significant impact on the attitudes of doctors wrestling with scarce time and resources.

\section{The Impact of the Health Care System}

The type of health care system not only determines how much influence different actors in the policy process hold but also affects the attainable range and effectiveness of policy options. Dutch citizens who do not purchase health insurance have had a significant impact on the new Dutch regulation for undocumented migrants. The Ministry of HWS does not want to provide full reimbursement for care provision to undocumented 
migrants, as this could motivate providers to label uninsured Dutch citizens as unlawful residents. Moreover, it would create a loophole for providers to avoid the administrative hassle attached to uninsured legal residents at no cost to themselves. It could potentially undermine the insurance system, as citizens might realize that they could still access health care services even if they did not pay for their health insurance premiums. As a representative from the Ministry of HWS states: "We can't do some good in financing care for illegal migrants if it means ruining the insurance system as a result" (head of division, health insurance and treaties, Ministry of HWS, interview, November 22, 2007). Thus the Ministry of HWS refunds providers only 80 percent of the incurred cost for primary and emergency secondary care and 80-100 percent of the costs for elective secondary care depending on negotiations between the hospital and the Health Care Insurance Board. To prevent insurance fraud, secondary health care providers are supposed to check patients' identification. In this case, the institutional arrangements of the health care system directly influence the chosen policy solution.

The institutional structure of the NHS also influences English policy options. Providing health care to undocumented migrants does not jeopardize the functioning of the tax-funded health care system, but some problems in the NHS are exacerbated by the influx of overseas visitors (people who enter the country for work or leisure) needing care, and consequently they influence the policies. For instance, the representative from the Department of Health pointed out that insufficient capacity and concerns about the financial viability of the NHS are among the reasons for restricting free health care access for overseas visitors and thus also for unlawful residents. Tax funding and free health care access are strongly connected in the NHS system. Increasing numbers of overseas visitors could threaten the viability of this if they received free care without paying taxes. In 2004 the Department of Health tightened hospital-charging regulations for overseas visitors. The department's representative stressed how important it is for hospitals to establish whether somebody is an overseas visitor, since people host their family members for extended visits. "And they tend to be health visitors, they come over here on a family-visit visa, but actually, it's because auntie is poorly and we're going to get her into hospital while she's here" (policy head, Department of Health, Overseas Visitors Policy Unit, interview, December 7, 2007). Strict regulations for undocumented migrants are thus also related to policies for charging other groups, such as overseas visitors who are legally allowed to stay on a family-visit visa. 
The type of health care system influences political discourse and the expectations of the different actors. While England has an NHS tradition of "free care," the Dutch have "paid care." Although care is never really free in the NHS system, as it is funded by taxes, when individuals access the system, it is "free" at the point of service. In the end, both countries have to pay for the care to undocumented migrants. The important difference is that the payment or public subsidy to cover the costs of care to undocumented migrants is hidden in England, because providers are not directly reimbursed for services rendered. However, in the Netherlands, payment is made transparent, and therefore it becomes part of political discourse. Payment and subsidies are actively debated and discussed in the Netherlands, whereas they are assumed to be "free" in England where providers working under the NHS are used to waiting lists and playing the role of prioritizing care; in many ways they are asked to play a similar function under the restriction policies. Similarly, Dutch providers are used to giving everyone the same level of care in the fee-for-service system. With that expectation, they fight for a good care-reimbursement system, even for undocumented migrants.

The health care system affects the creation of specific restriction policies, too. In the NHS, providers' payments have never been tied directly to patients or services, so it would be difficult to create "paid care" restrictions in England. As a result, the system forces providers to think about the circumstances under which they should offer free care to people who have not paid prospectively. The system itself creates that particular framing of the question and leads to a particular restriction policy. In the Netherlands, the restriction policy is framed in the fee-for-service system. This system forces Dutch policy makers to think about how they should finance care for people who are by law excluded from health care insurance. The policy legacy of the British NHS led to restrictions at the point of service, while the Dutch insurance system focused more on financial restrictions.

\section{Similarities and Differences in Policy and Practice}

\section{Interpretation of Human Rights}

It became clear from the interviews at the Department of Health and the Ministry of HWS that lawyers in both England and the Netherlands always scrutinize new legislation to ensure that it complies with international law. Accordingly, national policies in both countries concerning health 
care access for undocumented migrants are carefully examined to see if requirements (e.g., article 12 of ICESCR) of human rights legislation are met. The respondent of the Department of Health says: "The reason why $A \& E$ treatment is free to all is because we consider that we have an international obligation to provide that kind of treatment free to all. That's why that exemption is there" (policy head, Department of Health, Overseas Visitors Policy Unit, interview, December 7, 2007). Human rights clearly have a place in the development of these policies, albeit a much-disputed one. In both countries, many NGOs think that the government is not fulfilling its obligations imposed under human rights law; NGOs frequently use human rights arguments to oppose national policies. One English NGO respondent says, "We have definitely used human rights as an argument, and the fact that the U.K. is violating these individuals' human rights by charging and deporting people" (head of policy and deputy CEO, African HIV Policy Network, interview, December 10, 2007). The difference in interpretation between governments and NGOs lies in the extent of the obligations that each party believes arise from human rights law. While the English government considers it an international obligation to provide free treatment for all in A\&E departments, they do not feel obliged to provide free, nonurgent secondary care. In the Netherlands, care is never provided for free, even in A\&E departments. Hospitals are reimbursed if the undocumented migrant is unable to pay the treatment costs. Many NGOs consider these restrictions on access to secondary care a violation of human rights.

Both English and Dutch formal policies acknowledge that undocumented migrants should receive treatment deemed immediately or medically necessary in the professional opinion of a physician. The meaning of "necessary care" is not interpreted uniformly within or between the two countries. The terms are not legally defined in either country, but both have provided guidance relating to the interpretation.

In the Netherlands, after long debate on the definition of "medically necessary care" between consecutive health care ministers and medical professionals, a committee was set up to define the term through the combined efforts of several medical professional associations (Bloemen 2007). In December 2007 the committee published a report stating that "medically necessary care" should be understood to include all services, which are part of the basic health insurance package (CMZ 2007). Only if care can be postponed and the expected duration of stay in the Netherlands is short may the scope of treatment be limited or withheld. However, if the duration of stay is unclear, the treatment for undocumented migrants 
should be no different from that for insured people. The Ministry of HWS (2008) accepted this report as a guideline for health care professionals.

At the time of research, governmental guidance in England suggested a narrower interpretation of "immediately necessary treatment." Documentation from the Department of Health described such treatment as that undertaken to save life or to prevent a condition from becoming life threatening. Treatment needed without delay to prevent permanent serious damage was also included (Department of Health 2004a). However, on March 30, 2009, the Court of Appeal issued a judgment that this guidance was unclear and thus unlawful (Department of Health 2009). The Department of Health (2009: 3) must now redraft its guidance on this issue, taking into consideration that "trusts should consider the likelihood of the person returning home when deciding what limits to place on the treatment."

\section{Barriers to Health Care Access}

In daily practice, access to primary care seems fairly similar in England and the Netherlands. Most GPs will treat undocumented migrants much like their regular patients. Nevertheless, in both countries some GPs exclude undocumented migrants. In the Netherlands some GPs referred undocumented migrants to colleagues or required payment before providing care (Kulu Glasgow et al. 2000). Recent research showed that GP care for undocumented migrants is concentrated in a limited number of GP practices (Veenema, Wiegers, and Devillé 2009). Nevertheless, access to primary care has improved in the last decade, as GPs have become more familiar with reimbursement facilities (the Linkage fund) and more inclined to treat undocumented migrants.

More and more English GP practices are asking to see official documentation prior to registering patients. This identification check could be a serious barrier to accessing care. An English NGO's respondent said, "Sometimes they [migrants] are refused even if it concerns immediately necessary treatment, because of course the people they are talking to are not doctors, they are admin" (project manager, London walk-in health clinic, Médecins du Monde, interview, December 10, 2007). Although English GPs may charge undocumented migrants at their own discretion and are encouraged to do so by the Department of Health (2004b), the system is not set up for this, because historically the NHS has always been free at the point of delivery. Respondents declared: “They don't have systems in place for charging, you know, the actual process doesn't exist 
in most GP's surgeries" (coordinator, Refugee Health Network, Medact, interview, December 4, 2007), and "It's a public system, we feel very uncomfortable charging people" (GP, London, interview, December 5, 2007).

Emergency lifesaving care is in general easily accessible in both countries. However, access to nonurgent secondary health care appears to be easier in the Netherlands. Dutch physicians interpret "medically necessary care" rather loosely, which allows them to provide almost all health services to undocumented migrants. The reimbursement system for Dutch hospitals removes financial incentives to restrict health care access. Despite this, there are some problems. Since 2006, secondary health care providers are obliged to check identification for all patients (Ministry of HWS 2006b), which could deter undocumented migrants from seeking care. In addition, the provision for "dubious debtors" in the hospital budget is occasionally inadequate, and therefore some hospitals have started charging undocumented migrants approximately $€ 100$ prior to treatment. Charging undocumented migrants is not national policy; providers adopt these regulations according to circumstances, such as a high local density of migrants. Dutch providers are put under pressure, as there are almost no legal restrictions at point of delivery. Some have started to increase their efforts to meet the costs of care and thus "restrict" access through payment. Although friends or family can often pay these charges, they may seriously impede access to health care services for the most destitute.

In England, nonurgent secondary care is often difficult to access. Undocumented migrants are entitled to this care only if they can pay for it, which the vast majority cannot. In practice, these regulations are not implemented uniformly: some hospitals, for instance, provide HIV treatment without expecting payment; others provide treatment, but use all available means to gain reimbursement. This may explain why undocumented migrants, even those from high-risk countries, are refraining from being tested or treated for HIV. Moreover, although hospitals are obliged by law to provide immediately necessary care, if the patient cannot pay for the services, the hospital loses the cost of the provision. Understandably, hospitals try to limit the number of undocumented patients that they treat to avoid running up a deficit. Because of the absence of a reimbursement system for undocumented migrants, English providers are pressured to restrict access at the point of delivery. Driven by financial motives, hospital executives often interpret "immediately necessary care" more restrictively than physicians. They try to put pressure on physicians to do the same, as they are concerned not just with patients but also with 
the hospital's finances. Even though hospitals must charge undocumented migrants, they are not allowed to refuse to give immediately necessary care. According to the respondent from the Department of Health, charges should have no influence on access to care: "We are very clear that where the treatment is considered immediately necessary, you treat first and worry about whether they should be paying for it later. It is also a point worth making that charging regulations are just that, they do not give a NHS body the right to refuse to treat someone, only to charge them for it" (policy head, Department of Health, Overseas Visitors Policy Unit, interview, December 7, 2007).

However, in practice the charging regulations can be a problem. When NHS trusts treat undocumented migrants, it is compulsory for the trust to send bills to the patient to try to recover the cost. Trusts have the discretion to write off the debt if the immigrant clearly does not have the means to pay, but they may not do so until treatment is completely finished. Confronting these patients with bills during the course of treatment often acts as a deterrent to follow-up care. Patients might also be sent to the overseas visitors manager before they can see a doctor. When they are told that they will have to pay for their treatment, some are scared off and leave the hospital, even though they have the right to receive care.

Access to mental health care appears to be similar in both countries (PICUM 2007). At the primary care level, it is reasonably accessible for undocumented migrants, but at the secondary level, mental health care services are often denied. This is clearly illustrated by a comment from an English psychologist:

Well I work in the primary, the first level of service ... and when we want to refer our clients on to secondary services it becomes, it can become quite tricky. And sometimes it's not possible. So then we have to keep the client in our service at our level, which isn't always appropriate for the client. Or we have to let them go, knowing that they will not receive any further care. So that's difficult. (Psychologist, primary care trust, interview, January 28, 2008)

This is a serious issue because there are many mental health problems among undocumented migrants, linked to the difficulties they face in the host country and their anxiety about being apprehended and deported (Van den Muijsenbergh 2004; Pourgourides 2007). The only exception made for providing free, secondary mental health care to undocumented migrants is when it concerns compulsory treatment, which is paid for by the government. 


\section{Lifting Barriers}

Governmental guidance on interpreting national policies is obviously important, but no less important is how physicians interpret "immediately/ medically necessary care." Just as the responsible government departments from both countries adhere to different interpretations, there are also striking differences between English and Dutch doctors' opinions in this matter. Most Dutch doctors interpret "medically necessary" liberally; in their opinion undocumented migrants and citizens should have equal access to medical services. As the representative of the Dutch medical association said, "In a civilized country we wouldn't want to use different criteria for foreigners" (policy adviser, professional medical association, interview, November 21, 2007).

Individual physicians have some discretionary power, as their medical judgment is essential to decide whether treatment is medically necessary. Most feel responsible for providing care on the basis of medical need. Once they have established the need, they will not turn a patient away without appropriate treatment. In England especially, this has led to situations where "immediately necessary treatment" is interpreted more broadly than intended by the Department of Health. This is illustrated by the fact that the English health care workers indicated that they had found ways to work around the system, which allowed them to provide free secondary care to undocumented migrants. Not recording the fact that patients are undocumented or referring directly to another doctor rather than via administrative staff were among the ways mentioned. However, although doctors may want to treat their patients, several interviewees indicated that this could prove difficult because patients often have to get past frontline staff members who may require certain documentation. Hence doctors are not the only actors who have discretionary power at the micro level.

Interestingly, one English interviewee suggested that access to services might be better if the system were set up for charging. Currently there are significant numbers of GPs who exclude undocumented migrants from registering because they do not wish to provide free treatment. If GPs could more easily invoice people, they might be more willing to register these migrants.

\section{Discussion}

As we hope to have shown, the structure of the health care system affects the creation of specific restriction policies. The NHS system is set up 
so that people pay for it prospectively in their taxes; care is always free at the point of service. As a result, the system "forces" policy actors to think about the circumstances under which free care should be provided to people who have not paid prospectively. Restrictions at the point of service (limited list of services) fit better into an NHS system than financial restrictions. In contrast, the private insurance system is set up so that people insure themselves against health care costs, which are reimbursed afterward. This system "forces" policy actors to reflect on how to finance care for people who are by law excluded from health care insurance. The private system inclines more to financial restrictions than to restrictions at point of service. Thus the health care system itself creates a particular frame for the question, leading to a particular restriction policy.

Similarly, Dutch providers are more inclined to develop financial barriers than English providers. That may sound dramatic, but in practice, most cases do have access, as undocumented migrants have more or less the same entitlements as Dutch citizens and costs are largely reimbursed from specific funds. The English situation is more dichotomous in its treatment of undocumented migrants. As the HIV case showed, either you are in and receive free care or you are out and receive no care at all. In England, nonurgent secondary care is often difficult to access. This leads to the paradox that systems with financial restrictions could be more accessible to undocumented migrants than systems that offer free care with the exclusion of some services.

The way rules are interpreted and followed by health care providers and doctors varies in both countries. The majority of interviewees knew of situations where charging regulations were applied strictly, were sometimes abused, but were also applied leniently. These subtle tactics or mechanisms could ease or restrict access to medically necessary care. Similarly, the concept of medically necessary care, an important criterion for access to care, is not uniformly interpreted. While the interpretation varies in both countries, in general the concept is interpreted more loosely in the Netherlands than in England.

Policies on health care for undocumented migrants are linked to other policy goals, such as discouraging undocumented immigrants or protecting funding or the scarce resources (e.g., doctors) of the health care system. According to the respondents, macroeconomic arguments about the cost of undocumented immigrants did not play a large role in developing restrictive policies. From the perspective of Dutch policy makers, health care system funding is not endangered by undocumented migrants but by legal uninsured citizens who abuse the system when they present them- 
selves as illegal citizens. Similarly, the financial viability of the English NHS is endangered by legally staying overseas visitors who use care services for free without paying taxes. Concerns about the consequences of treating undocumented migrants generously seem to play a larger role in developing restrictive policies than concerns about macroeconomic treatment costs. In both countries, the institutional setting hinders the development of a "tailor-made policy" for undocumented migrants, even though the different systems generated different reasons for the absence of such a policy. Both countries have inherited a policy of combating misuse of the health care system by people who stay legally in the country. However, these groups of people are not the same in both countries. The English public NHS system with free care for all is wrestling with the problem of overseas visitors, while the Dutch health care system based on private insurance has to deal with its own uninsured citizens. Both systems confront undocumented immigrants with measures that have been developed for other health care users as well and could threaten their financing. The public system tries to prevent undeserved free use by nonresidents staying legally in the country, while the private system tries to prevent legal residents acting like free riders. In addition to such factors as antiimmigration attitudes, cost concerns, and the role of interest groups (doctor organizations), this study uncovered a new impact factor not mentioned in the literature: restrictive policies for undocumented migrants might be a side effect of measures intended for legal residents. This connection with health care policies for legal residents could be an important factor that explains why undocumented migrants are confronted with measures that hinder access to "the enjoyment of the highest attainable standard of physical and mental health" in the country (ICESCR, art. 12). Further international research is needed to test this hypothesis.

Another notable difference revealed by the comparative analysis is the role played by medical associations. English doctors more than Dutch doctors accept that the government ultimately decides the rules for undocumented migrants. The capacity of English medical associations to lobby government is impaired because of internal rifts among doctors on the issue of entitlement. The Dutch medical association lobbies heavily for cost reimbursement. The differences between English and Dutch medical associations should be interpreted less as differing ethical positions than as a reflection of differing policy paths or inheritances. Both the political and health care systems structure doctors' expectations. Dutch doctors' organizations operate within a neocorporatist model that creates a tradition of influence on all kinds of health policies including those for 
undocumented migrants. Working under the NHS in the United Kingdom, doctors are used to waiting lists and taking on the role of prioritizing care, which could pressure them to accept some restrictions for undocumented migrants at the point of service. In contrast, Dutch doctors are used to giving everyone the same level of care. With that expectation, and the fact that most Dutch doctors are private entrepreneurs paid by the fee-forservice system, they fight for a good reimbursement system for undocumented migrants. More than NGOs, doctors' organizations are crucial for the lobbying power that can be generated in the interest of a vulnerable and unorganized group of people. However, their lobbying power and concern with undocumented migrants are influenced by the system in which they work.

This study shows the importance of a good reimbursement system and adequate resources to treat undocumented migrants. Formal regulations that aim to guarantee access to health care for undocumented migrants cannot prevent problems of access if, for instance, financial incentives steer providers in another direction. Ethical considerations and human rights arguments may lose force if resources are limited or the financial responsibility is laid down elsewhere. The financial and practical organization of care for undocumented migrants is at least as relevant as the juridical part of guaranteeing access, because these rightful claimants find it difficult to claim their rights with the aid of litigation. Legal systems assume that violations of rights will be discovered by the rights-holders themselves, as they are the ones harmed (Stone 2002). We may safely expect the willingness to bring grievances to be low among undocumented migrants, since they tend to hide from the authorities. An important lesson to be learned from this study is that the provision of medically necessary care cannot be secured unless certain prerequisites are met.

Many Western countries limit access to health care for undocumented migrants and justify this by stating that their legislation stipulates that emergency/urgent/essential/immediately necessary medical care must always be provided (Romero-Ortuno 2004). It is not enough, however, to put this into legislation without ensuring the practical arrangements to make it happen. Necessary prerequisites include substantive financial reimbursements for health care providers, because the provision of medically necessary care will inevitably be at risk when providers lose money as a consequence of treating undocumented migrants. Action needs to be taken to remove practical barriers in accessing necessary health care services. Requests for official identification or invoices for services rendered should not deter people from accessing care, and this should be made 
clear to both doctors and patients. There should be guarantees to ensure that nonmedical staff (e.g., receptionists) are not allowed to stop undocumented migrants from seeing a doctor, so that doctors can assess whether treatment is medically necessary.

Another problem of legislation aimed at guaranteeing access to health care for undocumented migrants is the interpretation of "necessary medical care." Governments can solve this problem by applying the same definition used for the basic benefit package and excluding any treatment that falls under the supplementary insurance package. Although these solutions can be complicated for health systems that broadly define the basic benefit package, it could break down barriers that governments never intended to create for undocumented migrants.

\section{References}

Abbing, H. R. 2006. Recent Developments in Health Law in the Netherlands. European Journal of Health Law 13:133-142.

Ashcroft, R. E. 2005. Standing Up for the Medical Rights of Asylum Seekers. Journal of Medical Ethics 31:125-126.

Béland, D. 2010. Reconsidering Policy Feedback: How Policies Affect Politics. Administration and Society 42:568-590.

Bloemen, E. 2007. Start van de Commissie (Beginning of the Committee). Medisch Contact 62:88.

Brodkin, E. Z. 2008. Accountability in Street-Level Organizations. International Journal of Public Administration 31:317-336.

Brodkin, E. Z., and M. Majmundar. 2010. Administration Exclusion: Organizations and the Hidden Costs of Welfare Claiming. Journal of Public Administration Research and Theory 20:827-848.

Burnett, A., and M. Peel. 2001. Asylum Seekers and Refugees in Britain: What Brings Asylum Seekers to the United Kingdom? British Medical Journal 322:485-488.

Buse, K., N. Mays, and G. Walt. 2005. Making Health Policy. Maidenhead, UK: Open University Press.

Calavita, K. 1996. The New Politics of Immigration: "Balanced-Budget Conservatism" and the Symbolism of Proposition 187. Social Problems 43:284-305.

Chauvin, P., I. Parizot, and N. Simonnot. 2009. Report of the European Observatory: Access to Health Care for Undocumented Migrants in Eleven European Countries. Paris: Médecins du Monde.

CMZ (Commissie Medische Zorg) voor (dreigend) uitgeprocedeerde asielzoekers en illegale vreemdelingen. 2007. Arts en vreemdeling (Physician and Alien). Official report. Utrecht: KNMG, LHV, NVvP, Orde van Medisch Specialisten and Pharos. 
Cole, P. 2007. Human Rights and the National Interest: Migrants, Healthcare, and Social Justice. Journal of Medical Ethics 33:269-272.

Council of Europe. 2006. Resolution 1509. Human Rights of Irregular Migrants. Parliamentary Assembly of the Council of Europe, June 27. http://assembly.coe.int/ main.asp?Link=/documents/adoptedtext/ta06/eres1509.htm (accessed June 17, 2008).

De Groot, R. 2005. Right to Health Care and Scarcity of Resources. In Health Law, Human Rights, and the Biomedicine Convention, ed. J. K. M. Gevers, E. H. Hondius, and J. H. Hubben, 49-59. Leiden, Netherlands: Nijhoff.

Department of Health. 2003. Proposed Amendments to the National Health Service (Charges to Overseas Visitors) Regulations 1989: A Consultation. July 29. www .dh.gov.uk/en/Publicationsandstatistics/Publications/PublicationsPolicyAnd Guidance/DH_4050473 (accessed June 17, 2008).

- 2004a. Implementing the Overseas Visitors' Hospital Charging Regulations. April 21. www.dh.gov.uk/en/Publicationsandstatistics/Publications/Publications PolicyAndGuidance/DH_4080313 (accessed June 17, 2008).

- 2004b. Proposals to Exclude Overseas Visitors from Eligibility to Free NHS Primary Medical Services. August 13. webarchive.nationalarchives.gov.uk/+/www .dh.gov.uk/en/Consultations/Closedconsultations/DH_4087618 (accessed October 13, 2010).

- 2009. Failed Asylum Seekers and Ordinary/Lawful Residence; and When to Provide Treatment for Those Who Are Chargeable. April 2. www.dh.gov.uk/ en/Publicationsandstatistics/Lettersandcirculars/Dearcolleagueletters/DH_097384 (accessed June 21, 2009).

Dwyer, J. 2004. Illegal Immigrants, Health Care, and Social Responsibility. Hastings Center Report 34 (5): 34-41.

Fallek, S. B. 1997. Health Care for Illegal Aliens: Why It Is a Necessity. Houston Journal of International Law 19:951-981.

General Medical Council. 2006. About Good Medical Practice. www.gmc-uk.org/ guidance/good_medical_practice.asp.

Glaser, W. A. 1991. Health Insurance in Practice: International Variations in Financing, Benefits, and Practice. San Francisco: Jossey-Bass.

. 1994. Doctors and Public Authorities: The Trend toward Collaboration. Journal of Health Politics, Policy and Law 19:705-727.

Gordon, I., K. Scanlon, T. Travers, and C. Whitehead. 2009. Economic Impact on the London and UK Economy of an Earned Regularisation of Irregular Migrants to the UK. Official report. London: Greater London Authority.

Hacker, J. S. 2004. Review Article: Dismantling the Health Care State? Political Institutions, Public Policies, and the Comparative Politics of Health Reform. British Journal of Political Science 34:693-724.

Hall, P. 2006. Failed Asylum Seekers and Health Care. British Medical Journal 333:109-110.

Heclo, H. 1974. Modern Social Politics in Britain and Sweden: From Relief to Income Maintenance. New Haven, CT: Yale University Press. 
Hemerijck, A. 2001. De institutionele beleidsanalyse: Naar een intentionele verklaring van beleidsverandering (Institutional Policy Analysis: Towards an Intentional Explanation of Policy Change). In Handboek Beleidswetenschap, ed. T. A. Abma and R. J. In 't Veld, 83-95. Meppel, Netherlands: Boom.

Home Office. 2007. Enforcing the Rules. A Strategy to Ensure and Enforce Compliance with Our Immigration Laws. Report. March. London: Central Office of Information.

House of Commons Health Committee. 2005. New Developments in Sexual Health and HIV/AIDS Policy: Third Report of Session 2004-2005: Volume 1. London: Stationery Office Limited.

Jaklevic, M. C. 2001. This Side of the Ethical Border. Modern Healthcare 31:52-54.

Kulu Glasgow, I., D. De Bakker, M. Weide, and S. Arts. 2000. Illegalen aan de poort van de gezondheidszorg: Toegankelijkheid en knelpunten in de zorg van huisartsen, verloskundigen en spoedeisende hulpafdelingen (Illegal Immigrants at the Door of Health Care Services: Access and Obstacles to Care from GPs, Obstetricians and Accident and Emergency Departments). Utrecht: NIVEL.

Landelijke Commissie Medische Aspecten van het Vreemdelingenbeleid (LCMAV). 2004. Medische Aspecten van het Vreemdelingenbeleid (Medical Aspects of Immigration Policies). Official report. The Hague: Ministry of Justice/Ministry of Health, Welfare, and Sports.

Lipsky, M. 1980. Street-Level Bureaucracy: Dilemmas of the Individual in Public Services. New York: Sage.

Lowi, T. J. 1972. Four Systems of Policy, Politics, and Choice. Public Administration Review 32:298-310.

Ministry of Health, Welfare, and Sports (Ministry of HWS). 2006a. Stroomlijning financiering zorg aan illegalen (Streamlining Finance for Care for Illegal Migrants). December 18. www.minvws.nl/kamerstukken/z/2006/stroomlijning-financiering -zorg-aan-illegalen.asp.

- 2006b. Identificatieplicht in de zorg (Identification Requirements in Health Care). December 21. www.minvws.nl/actueel/vraag-en-antwoord/identificatieplicht -in-de-zorg/default.asp.

- 2008. Nota naar aanleiding van het verslag (Paper in Response to the Report). March 3. www.minvws.nl/notas/z/2008/31-249-nota-naar-aanleiding-van-het -verslag.asp.

NHS Executive. 1999. Overseas Visitors' Eligibility to Receive Free Primary Care. HSC 1999/018. Health Service Circular. London: Department of Health.

Okie, S. 2007. Immigrants and Health Care at the Intersection of Two Broken Systems. New England Journal of Medicine 357:525-529.

Organisation for Economic Co-operation and Development (OECD). 2009a. OECD Stat Extracts - International Migration Database. December 14. http://stats.oecd .org/index.aspx?lang=en.

2009b. International Migration Outlook: SOPEMI 2009. Paris: OECD.

Pierson, P. 1993. When Effect Becomes Cause: Policy Feedback and Political Change. World Politics 45:595-628. 
Platform for International Cooperation on Undocumented Migrants (PICUM). 2007. Access to Health Care for Undocumented Migrants in Europe. Brussels: PICUM.

Pollard, A. J., and J. Savulescu. 2004. Eligibility of Overseas Visitors and People of Uncertain Residential Status for NHS Treatment. British Medical Journal 329:346-349.

Pourgourides, C. 2007. Dilemmas in the Treatment of Asylum Seekers. Psychiatry 6:56-58.

Ragin, C. 1987. The Comparative Method. Berkeley: University of California Press.

Romero-Ortuno, R. 2004. Access to Health Care for Illegal Immigrants in the EU: Should We Be Concerned? European Journal of Health Law 11:245-272.

Schäfer W., M. Kroneman, W. Boerma, M. van den Berg, G. Westert, W. Devillé, and E. van Ginneken. 2010. The Netherlands: Health System Review. Health Systems in Transition 12, no. 1 .

Scharpf, F. W. 2000. Institutions in Comparative Policy Research. Comparative Political Studies 33:762-790.

Singer, R. 2004. Asylum Seekers: An Ethical Response to Their Plight. Lancet 363:1904.

Steinmo, S., and J. Watts. 1995. It's the Institutions, Stupid! Why Comprehensive National Health Insurance Always Fails in America. Journal of Health Politics, Policy and Law 20:329-372.

Stone, D. 2002. Policy Paradox: The Art of Political Decision Making. London: Norton.

Taylor, K. 2009. Asylum Seekers, Refugees, and the Politics of Access to Health Care: A UK Perspective. British Journal of General Practice 59:765-772.

United Nations Educational, Scientific and Cultural Organisation (UNESCO). 2005. Migration > Glossary > Migrant. September 13. portal.unesco.org/shs/en/ev.php -URL_ID=3020\&URL_DO=DO_TOPIC\&URL_SECTION=201.html.

Van den Muijsenbergh, M. 2004. Ziek en geen papieren: Gezondheidszorg voor mensen zonder geldige verblijfsvergunning (Ill without Papers: Health Care for People without a Residence Permit). Utrecht: Pharos.

Van der Heijden, P. G. M., G. Van Gils, M. Cruijff, and D. Hessen. 2006. Een schatting van het aantal in Nederland verblijvende illegale vreemdelingen in 2005 - in opdracht van het Ministerie van Justitie (An Estimate of the Number of Illegal Foreigners in the Netherlands in 2005 - Commissioned by the Ministry of Justice). Utrecht: IOPS.

Veenema, T., T. Wiegers, and W. Devillé. 2009. Toegankelijkheid van gezondheidszorg voor "illegalen" in Nederland: Een update (Accessibility of Health Care for "Illegal Migrants" in the Netherlands: An Update). Utrecht: NIVEL.

Weatherley, R. 1980. Implementing Social Programs: The View from the Front Line. Paper presented at the annual meeting of the American Political Science Association, Washington, DC, August 28-31. 
